\title{
A rainfall enrichment system suitable for open field experiments in arid and semi-arid ecosystems
}

\author{
Equipo simulador de agua de lluvia para experimentos a campo \\ en ecosistemas áridos y semiáridos
}

Xin, Zhiming1; Jianqiang Qian²; Carlos A. Busso3; Bo Wu'1,4 Yajuan Zhu'; Jinxin Zhang ${ }^{5}$; Yonghua Li $^{4,5,6^{*}}$; Qi Lu ${ }^{4,6^{*}}$

1 Experimental Center of Desert Forestry, Chinese Academy of Forestry, Dengkou County, Inner Mongolia 015200, China.

2 College of Forestry, Henan Agricultural University, Zhengzhou 450002, China.

3 Departamento de Agronomía-CERZOS (CONICET), Universidad Nacional del Sur, 8000 Bahía Blanca, Buenos Aires, Argentina.

4 Institute of Desertification Studies, Chinese Academy of Forestry, Beijing 100091, China.

5 Research Institute of Forestry, Chinese Academy of Forestry, Beijing 100091, China.

6 Kumtag Desert Ecosystem Research Station, State Forestry Administration, Dunhuang, Gansu 736200, China.

* Corresponding authors: emails: lyhids@caf.ac.cn; Luqi@caf.ac.cn

\begin{abstract}
The predicted changes in precipitation patterns because of global change have profound effects on terrestrial ecosystems. In the present study, the principle and design details of a rainfall enrichment system (RAINES) for open field experiments in semi-arid and arid ecosystems are presented. The rainfall intensity, validity and uniformity of this experimental facility were also tested. During the period from 2008 to 2010, our data showed that the RAINES was able to simulate rainfall events with different rainfall sizes, frequencies and timing. The greatest advantage of the $R A I N E S$ was its high uniformity in rainfall distribution over a relatively large experimental surface area $\left(>65 \mathrm{~m}^{2}\right)$, which was important for experimental studies of semi-arid and arid ecosystems where vegetation distribution is sparse. The rainfall validity of $R A I N E S$ was steadily at $66 \%$ or higher as long as the hydraulic pressure

\footnotetext{
Ref. bibliográfica: Xin, Zhiming; Jianqiang Qian; Carlos A. Busso; Bo Wu; Yajuan Zhu; Jinxin Zhang; Yonghua Li; Qi Lu. 2020. "A rainfall enrichment system suitable for open field experiments in arid and semi-arid ecosystems". Lilloa 57 (1): 54-71. Fundación Miguel Lillo, Tucumán, Argentina. D.O.I.: doi.org/10.30550/j.lil/2020.57.1/4

> Recibido: 17/10/19 - Aceptado: 19/03/20

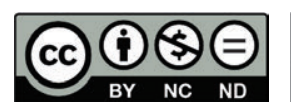


exceeded 1.4 KPa and the wind speed was below $2.5 \mathrm{~m} \mathrm{~s}^{-1}$. Since the RAINES is light-weight, inexpensive and versatile enough to be used to simulate various rainfall events with needed properties in remote fields, it is able to provide reliable simulated rainfall in the field for studying possible responses of soil and vegetation processes to rainfall change in arid and semi-arid ecosystems. The application of the RAINES will improve our understanding on the relationship between water availability and ecosystem processes in arid and semi-arid ecosystems, which will provide useful knowledge for the protection, restoration and sustainable management of semi-arid and arid desert ecosystems worldwide.

Keywords - Climate change; desert ecosystem; ecosystem response; experimental system; rainfall simulation.

\section{RESUMEN}

Los cambios predichos en los modelos de precipitación como resultado del cambio global tienen efectos profundos en los ecosistemas terrestres. Un equipo que simule la lluvia es una herramienta de investigación efectiva para explorar los efectos de los cambios en los modelos de lluvia sin varias restricciones naturales. En el presente estudio, se presentan los principios y detalles de diseño de un equipo simulador de lluvia (RAINES) para estudios a campo en ecosistemas áridos y semiaridos. También se determinaron la intensidad de lluvia, validez y uniformidad del RAINES. Durante el período 2008 al 2010, nuestros datos mostraron que el RAINES fue capaz de simular eventos de lluvia con diferentes cantidades, frecuencias y momentos de lluvia. La mayor ventaja del RAINES fue su gran uniformidad en la distribución de la lluvia sobre una superficie experimental relativamente grande $\left(>65 \mathrm{~m}^{2}\right)$. Esto es importante para estudios experimentales en ecosistemas áridos y semiáridos donde la distribución de la vegetación es dispersa. La validez de la lluvia provista por el RAINES fue al menos de $66 \%$ siempre y cuando la presión hidráulica excedió los 1.4 KPa y la velocidad del viento fue menor que $2.5 \mathrm{~m} \mathrm{~s}-1$. El RAINES es de bajo peso, no costoso y lo suficientemente versátil como para ser usado para simular varios eventos de lluvia bajo condiciones de campo distantes. Es capaz de proveer lluvia simulada en forma confiable en el campo para estudiar la respuesta de procesos en el suelo y la vegetación a cambios en la cantidad de lluvia en ecosistemas áridos y semiáridos. El uso del RAINES mejorará nuestro entendimiento en la relación entre la disponibilidad de agua y los procesos en ecosistemas áridos y semiáridos. También proveerá conocimiento útil para la protección, restauración y menejo sustentable de ecosistemas de desierto áridos y semiáridos a escala mundial. 


\section{INTRODUCTION}

Semi-arid and arid ecosystems cover more than $30 \%$ of the world's terrestrial surface. Variations in precipitation amount and timing as a result of global climate change may significantly alter the structure and function of water limited ecosystems such as deserts and sand dunes (Weltzin et al., 2003; Huxman et al., 2004a, 2004b; HeislerWhite, Knapp, Kelly, 2008). Schwinning, Sala, Loik, Ehleringer (2004) pointed out that, for many years, studies failed to explore how discontinuously water availability, especially those induced by rainfall pulse events, impacted arid ecosystem processes. Although recent studies have started to study the possible effects of rainfall properties (e.g. amount, frequency, timing) on the vegetation cover and ecosystem processes in arid and/or semi-arid regions (Weltzin et al., 2003; Schwinning et al., 2004; Huxman et al., 2004a, 2004b; Heisler-White et al., 2008), studying the ecological effects of rainfall pulses in natural environment might be difficult. This is because it involves long periods to trace the occurrence of natural rainfall and large uncertainties owing to uncontrollable properties (e.g. amount, duration, timing) of natural rainfall events (Weltzin et al., 2003; Schwinning et al., 2004). The rainfall simulator has been considered as a good research tool which allows that studies are conducted on the schedules of researchers, and not from those coming from natural events (Hudson, 1993).

Over the past 50 years, various types of rainfall simulators have been developed to support numerous research efforts across the world (Swanson, 1965; Renard, 1985; Hudson, 1993; Meyer, 1994; Humphry, Daniel, Edwards, Sharpley, 2002; Munster, Taucer, Wilcox, Porter, Richards, 2006; Chen, Lin, Huang, Mao, 2008). However, most rainfall simulators have been employed for hydrologic studies (Swanson, 1965; Renard, 1985; Hudson, 1993; Meyer, 1994; Humphry et al., 2002). Some researchers also used rainfall simulation to study how rainfall pulse affects vegetation and soil processes (Fay, Carlisle, Knapp, Blair, Collins, 2000; Weltzin et al., 2003; Munster et al., 2006; Chen et al., 2008; Nippert, Fay, Carlisle, Knapp, Smith, 2009; Robertson, Zak, Tissue, 2010). But, most field-based rainfall simulators have been only utilized for small plots, i.e., not larger than $10 \mathrm{~m}^{2}$ ground area (Zavaleta et al., 2003; Huxman et al., 2004a; Lee, Wu, Sigler, Oishi, Siccama, 2004; Patrick et al., 2007; HeislerWhite et al., 2008; Chen, Lin, Huang, Jenerette, 2009; Nippert et al., 2009; Patrick, Ogle, Bell, Zak, Tissue, 2009; Robertson et al., 2010). Thus, they are not suitable for semi-arid and arid ecosystems where vegetation is sparse. Even though some rainfall simulators can be applied for relatively larger plots, such as rotary sprinklers and rotating boom rainfall simulators (Hudson, 1993; Meyer, 1994; Munster et al., 2006; Chou, Silver, Jackson, Thompson, Allen Diaz, 2008), the rainfall distribution of these sprinklers usually lack homogeneity or incur high-cost labor and/or are expensive (Renard, 1985; Hudson, 1993; Meyer, 1994; Munster et al., 2006).

In the present study, a novel rainfall enrichment system (RAINES) for the field manipulation experiments in semi-arid and/or arid ecosystems was introduced. This experimental facility has a pair of rotating booms with multi-nozzles to conveniently simulate the natural rainfall events with different rainfall size, frequencies and timing over a large experimental plot (up to $12 \mathrm{~m}$ in diameter). This study aims to (1) 
describe the principle and design details of the RAINES, and (2) test the performance of $R A I N E S$ by measuring the rainfall intensity, validity and uniformity of the rainfall delivered by it.

\section{MATERIALS AND METHODS}

System requirements. - Due to the sparse vegetation distribution and high spatial heterogeneity in semi-arid and arid ecosystems, experimental plots should be large enough to accurately represent the characteristics of vegetation and soil in given regions (Weltzin et al., 2003). Besides, since many study sites in semi-arid and arid regions are located far from town, power and water sources, a simple and reliable rainfall simulator was required with regard to construction and labor cost for set up and operation. Since it was assumed that water would have to be transported to the study site, the ability to store water was also a key design consideration for the rainfall simulation system. Moreover, the rainfall distribution should be uniform over the plot in both intensity and validity (ratio of actual rainfall to simulated rainfall), and the application should be nearly continuous across the experimental plots.

System design.- The RAINES prototype (designed by Chuansen $\mathrm{Xu}$, Chinese Academy of Sciences, unpublished data) was used in the seedling cultivation in commercial nurseries, and its operational principle was based on reaction propulsion of water. The RAINES described here was modified from the irrigation system of earlier prototype designs. The RAINES comprised three major subsystems: spraying system, water control system and water supply system.

Spraying system.- The key equipment of RAINES was the spraying system, which included a pedestal, a rotor, a mast, a pair of rotating booms and 30 plastic nozzles (Figure 1, Table 1). The pedestal was made of concrete. It was used to fix the rotor with three screws (12 $\mathrm{mm}$ diameter) which were inserted into the pedestal within a symmetrical triangle arrangement (Figure 1, Table 1). The iron rotor was a cannular and airtight cylinder, which was divided into two parts. The diameter of the nozzles was about $1.2 \mathrm{~mm}$. The bottom part was used to fix the rotor. The upper part could rotate and was connected to the two rotating booms with screws (Figure 1, Table 1). A rotating boom (with the length of $6 \mathrm{~m}$ ) comprised three $2 \mathrm{~m}$-length hollow aluminum alloy pipes which were connected with AB-Rubber (Julong Chemical Industry Inc., Dongguan, China). The interior diameters of the three pipes were 2.8 $\mathrm{cm}, 2.6 \mathrm{~cm}$ and $2.4 \mathrm{~cm}$, respectively. At the end of each rotating boom, the alloy pipe was sealed by a cork (Figure 1, Table 1). In order to ensure the stable equilibrium of rotating booms, the vertical mast was connected with the rotating booms by two pairs of steel wires (Figure 1, Table 1).

A total of 30 non-equidistant nozzles were inserted in the rotating booms (Figure 2a). Water was permitted into the rotor by an inlet at the bottom of the rotor and it was evenly sprayed from the non-equidistant nozzles (Figure 1, Table 1). As water was sprayed from the nozzles, the rotating booms could be driven and run 


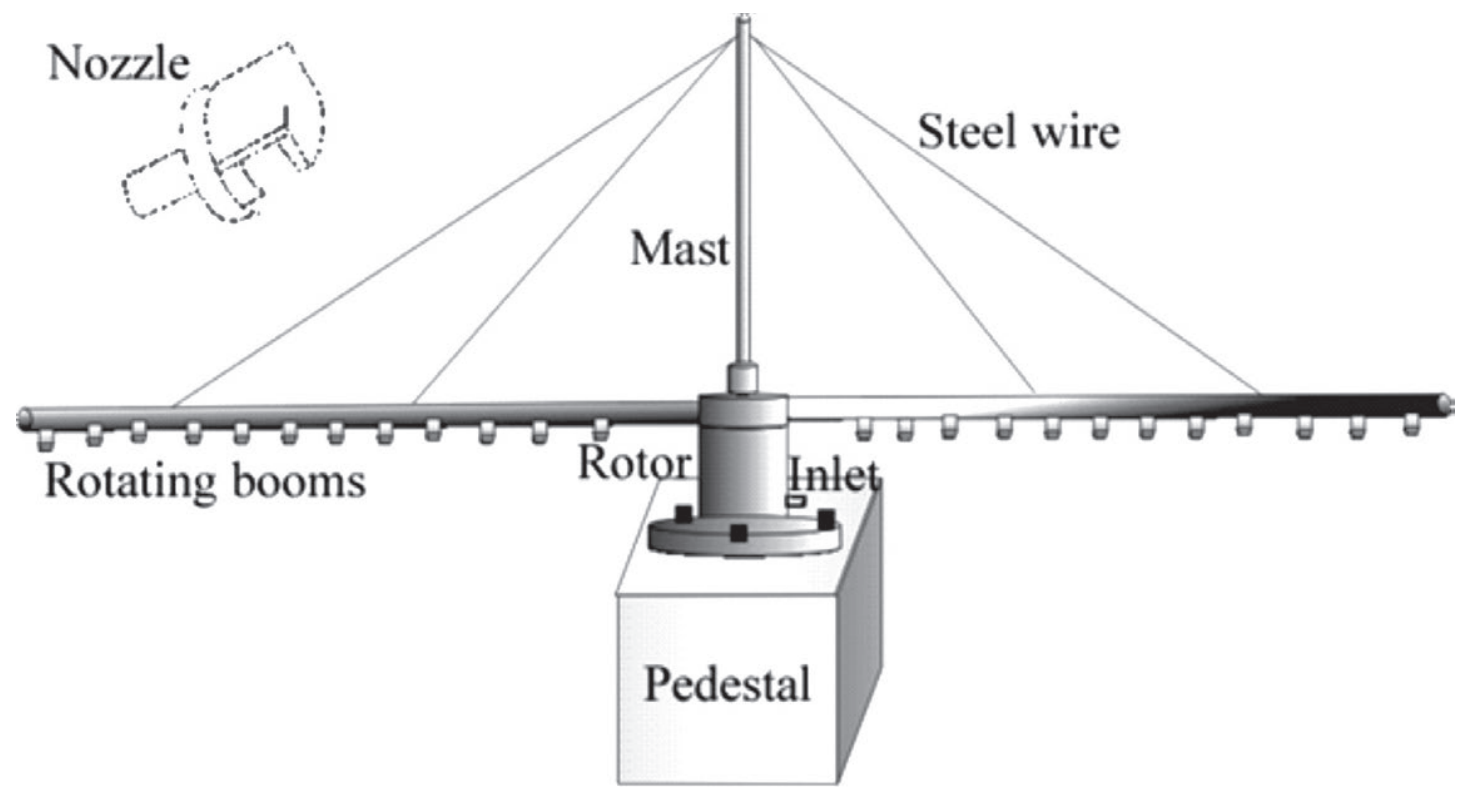

Fig. 1. The schematic layout of the spraying system prototype of RAINES in the field. The layout showed the pedestal, rotor, rotating boom, mast, steel wire and nozzle assembly. The pedestal was used to fix the rotor with three screws. The steel wire was used to ensure stable equilibrium of the rotating booms. Water flowed into the rotor from the inlet and sprayed out from the nozzles which were inserted in the rotating booms.

Table 1. The specifications of the rainfall enrichment system (RAINES).

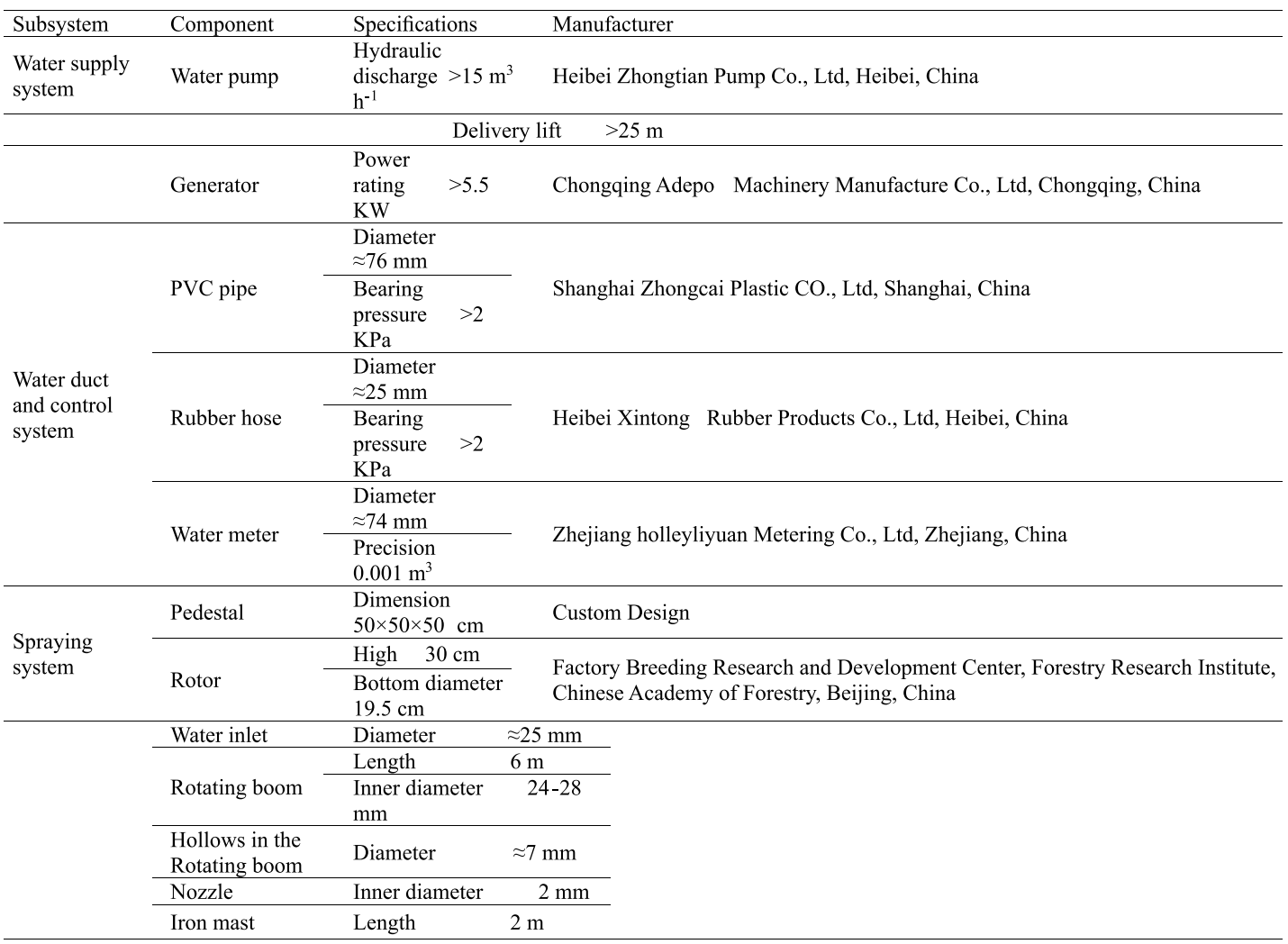




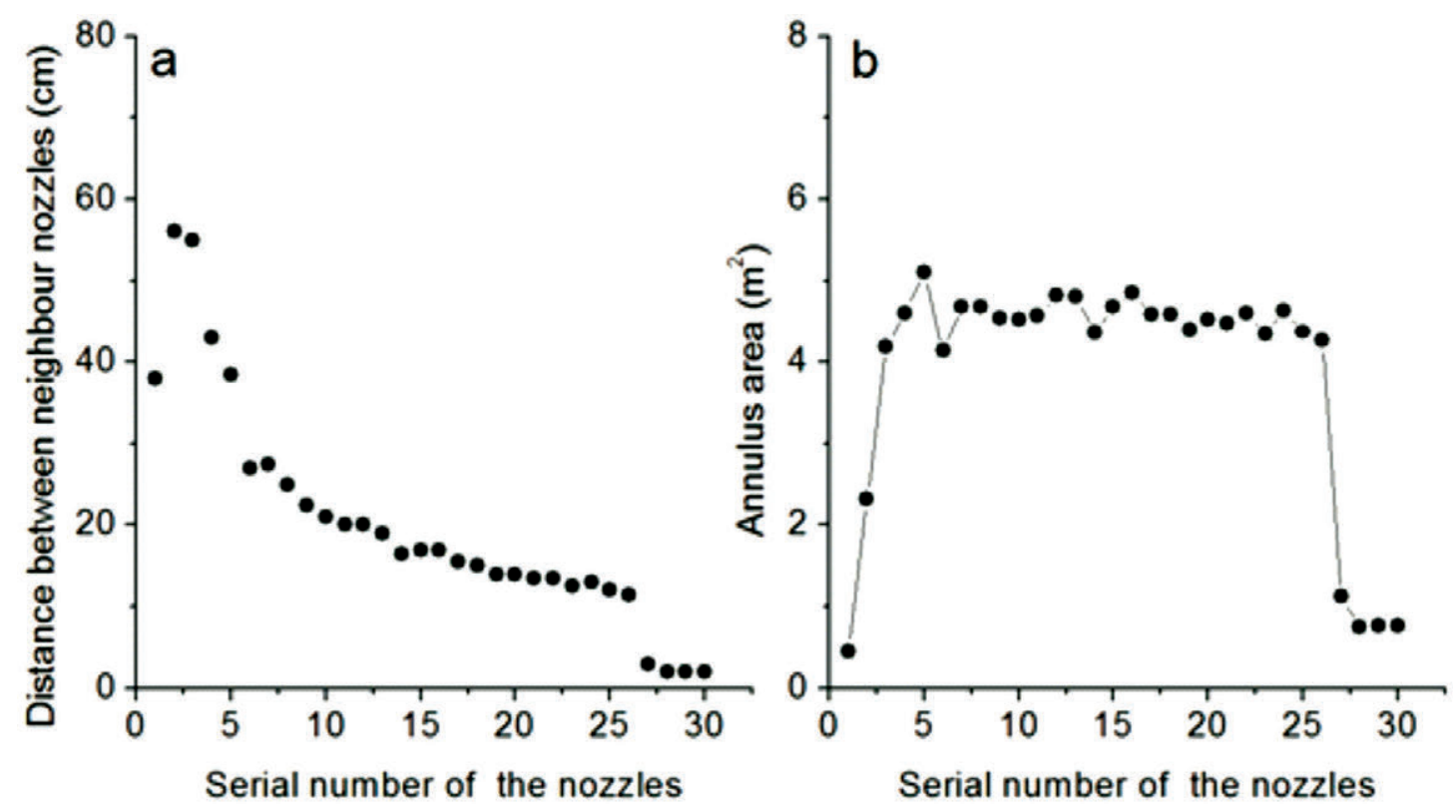

Fig. 2. The arrangement of the nozzles in the rotating booms of a RAINES. The origin of the coordinates was located at the rotor. (a) Distance between neighbor nozzles from the rotor to the end of a rotating boom. As the rotating booms run around the rotor, the nozzles could draw 30 concentric circles in the field. (b) The area arrangement of the 30 annulus (the areas between the two concentric circles) from the rotor to the edge of the field.

around the rotor by the reaction propulsion of water. Simultaneously, most of the 30 annulus areas (the areas between the two concentric circles) fluctuated slightly around $4.5 \mathrm{~m}^{2}\left(4.2-4.8 \mathrm{~m}^{2}\right)$ (Figure $2 \mathrm{~b}$ ), which could be expected to guarantee the high uniformity in rainfall distribution in the field $\left(>105 \mathrm{~m}^{2}\right)$.

Water control system. - The water control system, which comprised the water meters, hydro-valves, a series of PVC pipes and rubber hoses, connected the water supply system to the spraying systems (Figure 3, Table 1). Water flow rate was measured by the water meters and controlled by the hydro-valves. For the RAINES system, a water meter only monitored one spraying system to ensure the independence of the individual spraying system (Figure 3, Table 1).

Generally, the PVC pipes were the major connection channel, which were connected with ABS-Alloy (Julong Chemical Industry Inc., Dongguan, China). The rubber hoses were only used at the joints of water pumps or rotors.

Water supply system. - The water supply system provided not only water but also hydraulic pressure for driving the spraying systems (Figure 3, Table 1). Water was obtained from a nearby well, and then delivered to a reservoir (artificial pool) by a pipeline or a mill wheel. Generally, the reservoir was assembled at the geometric center of intended experimental plots so as to provide uniform water pressure to all spraying systems (Figure 3). The water storage capacity of the reservoir should be higher than the volume of water demanded by all the experiments for one time of rainfall simulation. The hydraulic pressure for driving the spraying system was 
about 1-2 Kpa, which was achieved by a water pump driven by a gasoline generator (Figure 3, Table 1).

Performance test in the field.- Three study sites were selected on the basis of natural rainfall gradient and logistical convenience (Figure S1). The study site Dengkou $\left(106^{\circ} 09^{\prime}-107^{\circ} 10^{\prime} \mathrm{E}, 40^{\circ} 09^{\prime}-48^{\circ} 572^{\prime} \mathrm{N}\right)$ mainly included three geographic parts: the plain in the northeast, the mountain in the northwest and the rest is sand dune. The mean altitude is $1950 \mathrm{~m}$ a.s.l. This study site belongs to the temperate monsoon climate, the mean annual temperature is $7.6^{\circ} \mathrm{C}$, the mean annual precipitation is $144.5 \mathrm{~mm}$, and the potential evapotranspiration is $2397 \mathrm{~mm}$. The experimental plots ( $106^{\circ} 43^{\prime}$ E, $40^{\circ} 24^{\prime} \mathrm{N}$ ) were dominated by Nitraria tangutorum Bobr., the other perennial species were Phragmites australis and Artemisia ordosica, and the common annual species were Psammochloa villosa and Agriophyllum squarrosum. The mean annual temperature of Minqin was $7.40^{\circ} \mathrm{C}$, and the mean annual precipitation was $115 \mathrm{~mm}$. The study site $\left(102^{\circ} 58^{\prime} \mathrm{E}, 38^{\circ} 34^{\prime} \mathrm{N}\right)$ was mainly a semi-fixed sand dune, and its vegetation was simple. Nitraria tangutorum Bobr. was the only shrub species at this site, without herbaceous species in dry years and only few annual species in wet years. The mean annual temperature of study site Dunhuang $\left(92^{\circ} 13^{\prime}-95^{\circ} 30^{\prime}\right.$

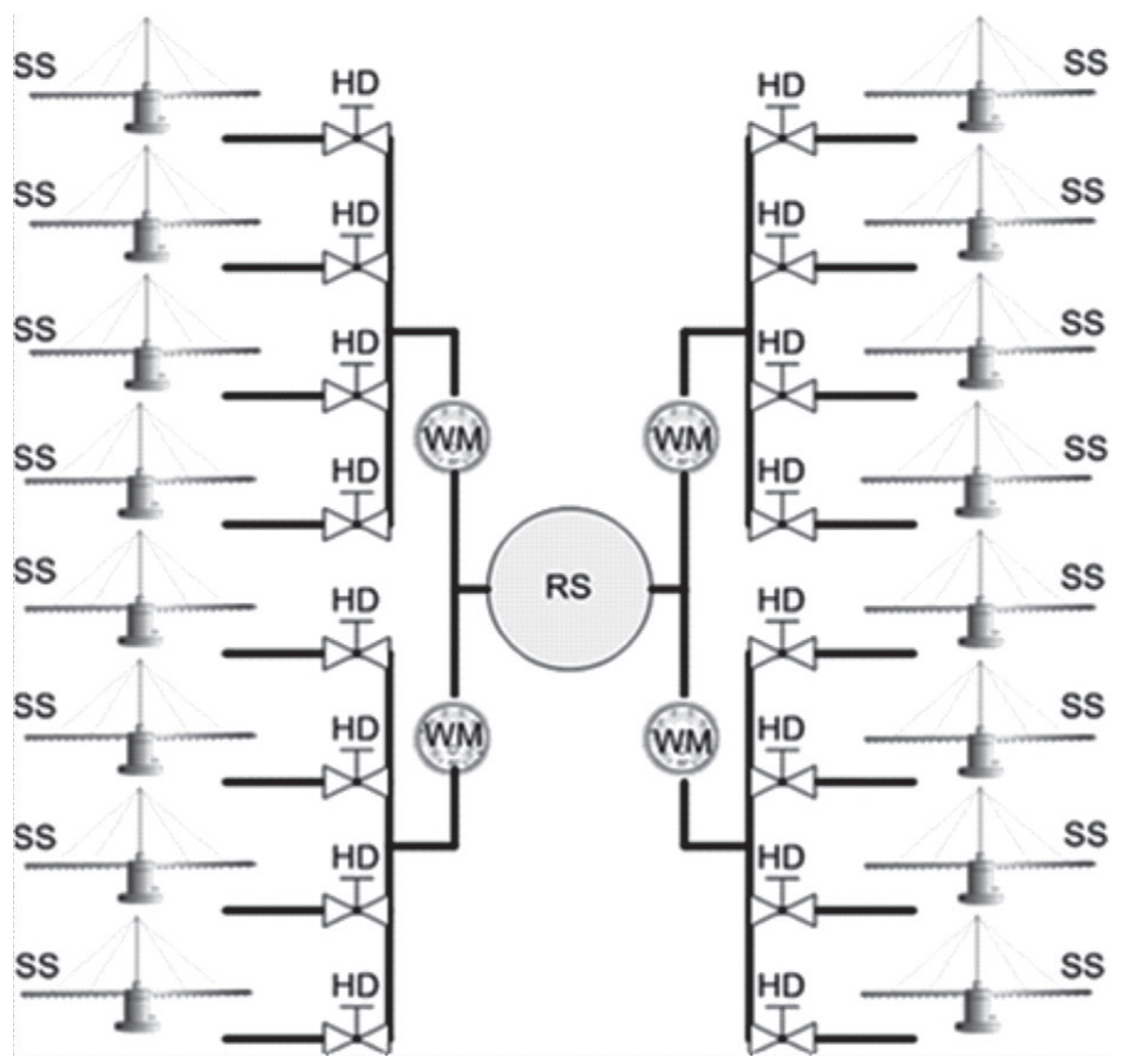

Fig. 3. Diagrams of RAINES systems employed in the fields. Water in a reservoir (RS) was transported to spraying systems (SS) with PVC pipes. Water meters (WM) and hydro valves (HD) were used to monitor and control the flow of water. Spraying systems (SS) were used to rainfall simulation. 
E, $39^{\circ} 53^{\prime}-41^{\circ} 35^{\prime} \mathrm{N}$ ) was $9.30^{\circ} \mathrm{C}$, the mean annual precipitation was $40 \mathrm{~mm}$ and the PET was about $2500 \mathrm{~mm}$. The dominant species at the study site $\left(94^{\circ} 43^{\prime} \mathrm{E}, 40^{\circ} 08^{\prime}\right.$ N) was Nitraria sphaerocarpa and Calligonum gobicum, with subdominated species Reaumuria soongorica, Alhagi sparsifolia. Nitraria $\mathrm{sp}$. is a dominant species of the characteristic zonal shrub vegetation in the western and north-western arid regions of China, where the mean annual precipitation was generally less than $300 \mathrm{~mm}$. This species is usually less than $70 \mathrm{~cm}$ in height and mainly occurs on fixed and semifixed sand dunes in the periphery of oasis or piedmont plains. At each study site, a total of 20 plots were randomly established. The diameter of the plot was $6 \mathrm{~m} ; 20$ plots were divided into 5 different rainfall treatment groups. Four of these 5 groups of plots received rainfall of different amounts from the RAINES system (Figure 3), representing $25 \%, 50 \%, 75 \%$ and $100 \%$ annual rainfall in three study sites.

To test the rainfall validity and intensity of the RAINES, the actual rainfall amount and duration were measured during 2008-2010 in all three test sites. The actual rainfall amount was determined with an 8-inch rainfall gauge, while the expected rainfall amount $(Y)$ was calculated as follows:

$$
Y=F \times T / A
$$

Where $F$ was the flow rate measured by water meters, $T$ was the rainfall duration which was collected by a stopwatch (PC894, Tianfu Electronic Co., Ltd, Shenzhen, China), $A$ was the area of the plot.

To further test how rainfall validity changes with wind and hydraulic pressure, a suite of independent $R A I N E S$ were operated during the period of June $5^{\text {th }} 8^{\text {th }}, 2009$ at the study site in Dengkou. The actual rainfall amount was measured with four 8 -inch rainfall gauges, and the expected rainfall amount was calculated by equation [1]. A hydro-valve and a hydraulic pressure gauge were connected with a water duct system in series. Hydraulic pressure could be controlled by the hydro-valve. Meanwhile, wind speed and wind direction were monitored by an auto-weather station (HOBO, H21-001, Onset Computer Corporation, USA).

The rainfall distribution was estimated by collecting and comparing rainfall in different coordinates 3 of selected test plots per site. The frequency of collecting rainfall was 5 minutes. Initial point of the rectangular coordinate system was at the rotor. $Y$ axis was north direction and $X$ axis was east direction. The rainfall at different coordinates was collected by bowls. The bowls were arranged equidistantly by placing them at intervals of $20 \mathrm{~cm}$ from one another up to $700 \mathrm{~cm}$ around the rotor at eight orientations (east, southeast, south, southwest, west, northwest, north and northeast). The diameter and height of bowls were $12.5 \mathrm{~cm}$ and $8.0 \mathrm{~cm}$, respectively. The water weight in each bowl was determined by an electronic scale (precision 0.1 g) (LP1002, Bailing Balance Instruments Co, Ltd., Changshu, Jiangsu Province, China). In addition, the rainfall duration was recorded with the stopwatch. 


\section{RESULTS}

Rainfall distribution.- As hydraulic pressure was higher than $1.4 \mathrm{KPa}$ and wind speed was less than $2.5 \mathrm{~m} \mathrm{~s}^{-1}$, the rainfall distribution was relatively uniform in the area of $200-500 \mathrm{~cm}$ from the rotor, which covered more than $50 \%$ area $\left(>65 \mathrm{~m}^{2}\right)$ of a plot (Figure 4). Simultaneously, the rainfall fluctuated significantly in the area of $0-200 \mathrm{~cm}$ and $500-600 \mathrm{~cm}$ from the rotor, which accounted about $41.7 \%$ area $(<25$ $\mathrm{m}^{2}$ ) of the plot (Figure 4).

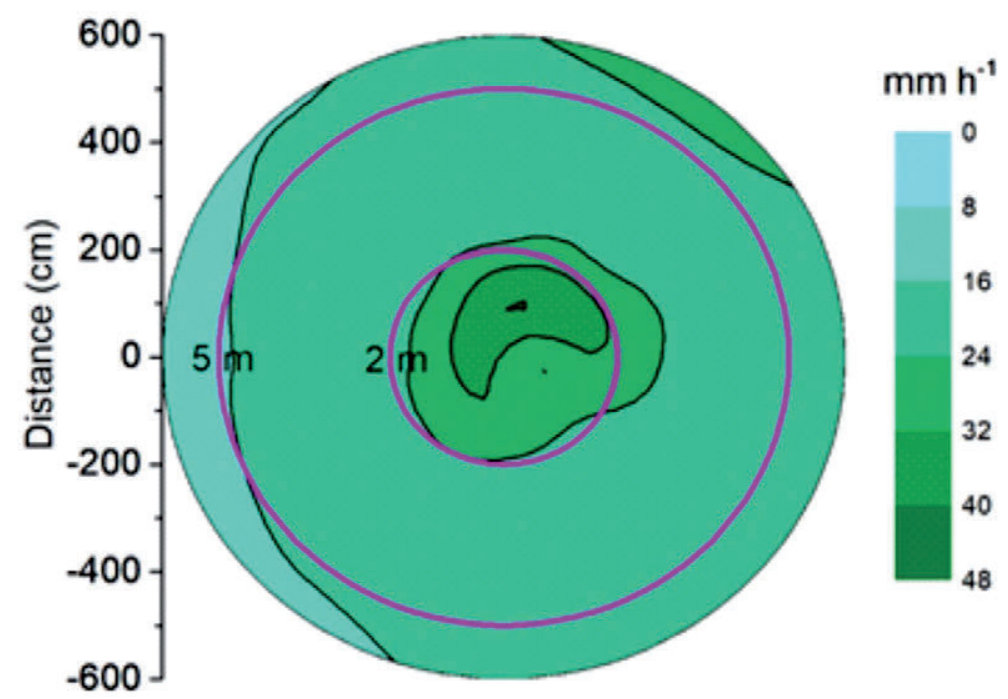

Fig. 4. Rainfall distribution of RAINES in an experiment plot at hydraulic pressure $1.4 \sim 1.5 \mathrm{KPa}$ and wind speed $2.1 \mathrm{~m} \mathrm{~s}^{-1}$ (south-west wind) within one hour period.

Rainfall validity. - The mean rainfall validity (ratio of actual rain amount to expected rainfall) was above $66 \%$ (Figure 5). Wind speed and hydraulic pressure were the two major factors influencing the rainfall validity (Figure 6). The rainfall validity remained unchanged when the wind speed varied from 1.2 to $2.2 \mathrm{~m} \mathrm{~s}^{-1}$, but started to decrease with wind speed when the wind speed exceeded $2.5 \mathrm{~m} \mathrm{~s}^{-1}$ (Figure 6a). On the other hand, the rainfall validity varied when the hydraulic pressure was below $1.3 \mathrm{Kpa}$, but reached relatively stable when the hydraulic pressure exceeded $1.4 \mathrm{KPa}$ (Figure 6b).

Rainfall intensity. - In all field tests, the actual required times were approximately equaled to the expected required times (Table 2). The RAINES at maximum could deliver $30 \mathrm{~mm}$ rainfall within 80 minutes. 


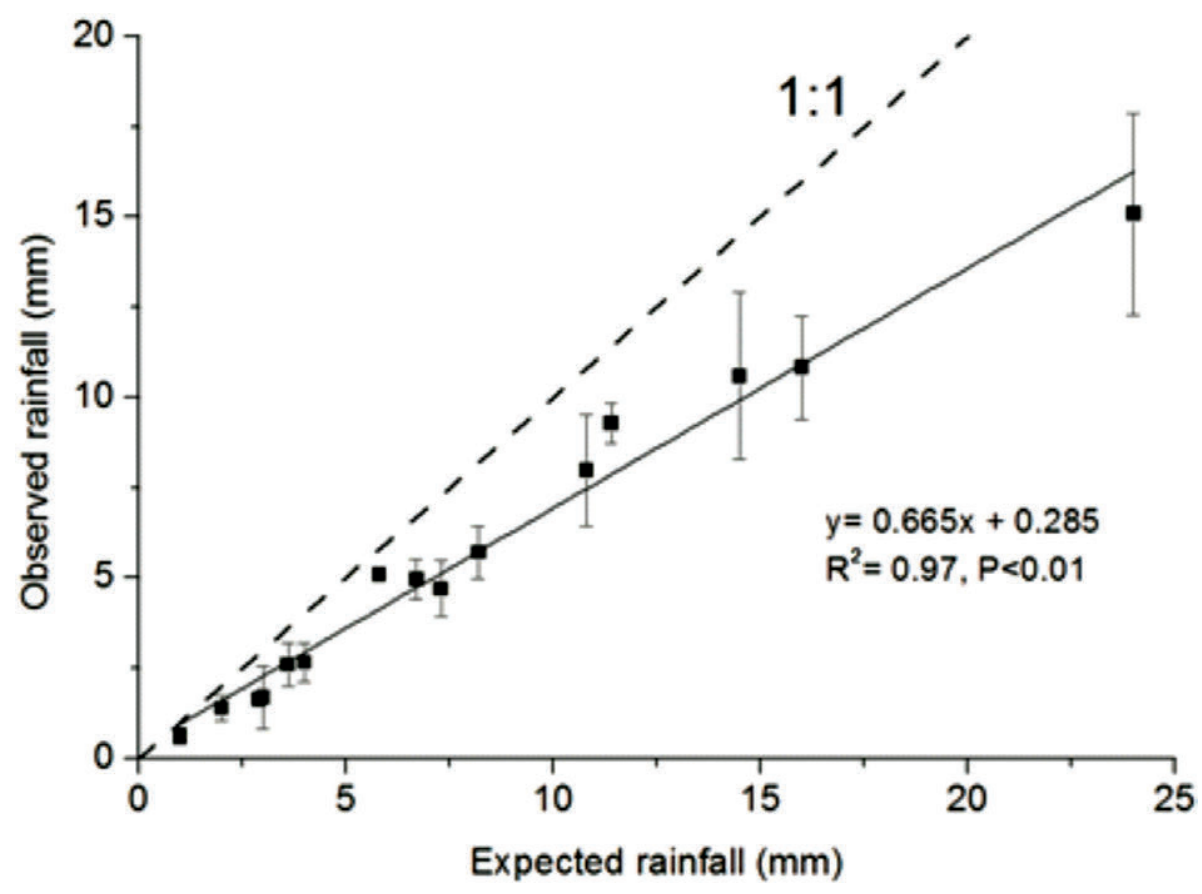

Fig. 5. Comparison between the expected rainfall with the observed rainfall using RAINES in the field test plots. The observed rainfalls were collected with an 8-inch rain gauge. Expected rainfall were calculated as $Y=F \times T / A$. Where $\mathrm{F}$ was the flow rate which was measured by a water meter, $T$ was the rainfall duration which was collected by a stopwatch, $A$ was the area of the plot. All the data were collected from the Dunhuang, Minqin and Dengkou sites in 2008-2010.

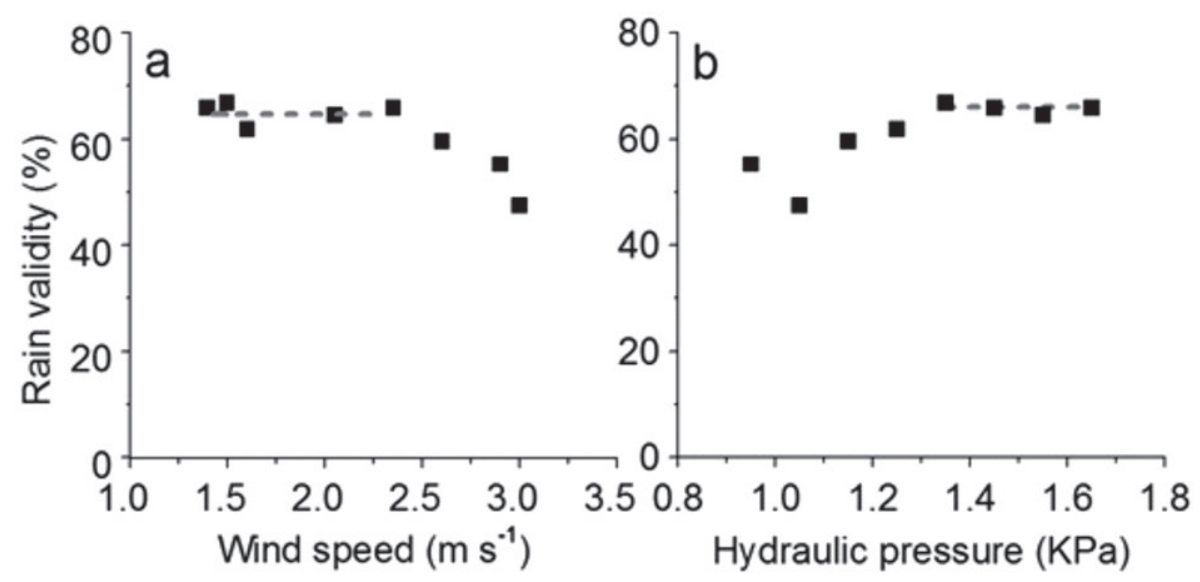

Fig. 6. Change in RAINES rainfall validity (ratio of observed rainfall to expected rainfall) with wind speed and hydraulic pressure.

\section{DISCUSSION}

RAINES performance. - The performance tests conducted at the three sites (Dunhuang, Minqin and Dengkou) during 2008-2010 proved that the RAINES was a reliable, simple, low labor cost and inexpensive rainfall device for simulating rainfall events with different rainfall sizes, frequencies and timing. The greatest advantage of the $R A I N E S$ was its high uniformity in rainfall distribution over a relatively large 
Table 2. Expected and observed rainfall time for different rainfall simulations with 1.4-1.5 KPa hydraulic pressure. Previous tests of the RAINES prototype showed that rainfall linearly increased with rainfall duration $(y=0.420 x-0.008$, unpublished data) at 1.4-1.5 KPa hydraulic pressure. Based on the equation, we estimated the expected time with different rainfall, and then compared the expected time with the observed time collected from Dengkou, Minqin and Dunhuang sites in 2008-2010.

\begin{tabular}{ccc}
\hline Rainfall $(\mathrm{mm})$ & Expected time (min.) & Observed time (min.) \\
\hline 2 & 4.8 & $4-6$ \\
\hline 5 & 11.9 & $11-14$ \\
\hline 10 & 23.8 & $20-26$ \\
\hline 20 & 47.6 & $44-52$ \\
\hline 30 & 71.4 & $65-76$ \\
\hline
\end{tabular}

experimental surface area $\left(>65 \mathrm{~m}^{2}\right)$, which was important for experimental studies in semi-arid and arid ecosystems where vegetation is sparse. A rainfall simulator which can cover a large-scale plot is crucial to the studies on the vegetation response to changes in water availability in these water limiting regions (Weltzin et al., 2003). The uniformity of rainfall distribution was also a key factor in rainfall manipulation experiments (Gilley, Mielke, Wilhelm, 1983). The RAINES had a pair of rotating booms with non-equidistant sprinklers, which not only encouraged a large spray area, but also increased the uniformity of rainfall distribution.

Rainfall intensity and validity were the other key indexes in evaluating the performance of rainfall simulators (Gilley et al., 1983; Weltzin et al., 2003; Dunkerley, 2008). Low rainfall intensity would lead to more water loss because of high temperature and low humidity in arid and semi-arid regions (Aboghobar, 1993). However, high rainfall intensity would raise surface runoff before water infiltrated into soil. The rainfall intensity of the RAINES was about $25.2 \mathrm{~mm} \mathrm{hr}^{-1}$, which was almost the maximum single rainfall intensity in most semi-arid or arid regions (Dunkerley, 2008), but did not cause any significant runoff during two hours' rainfall at our test sites. The rainfall validity of the RAINES was usually higher than $66 \%$ as long as the hydraulic pressure exceeded $1.4 \mathrm{KPa}$ and the wind speed was below $2.5 \mathrm{~m} \mathrm{~s}^{-1}$, which could be easily achieved in most cases in the field.

In addition, the design of the RAINES was simple. It means that the RAINES is not only inexpensive (Price of a RAINES was not more than $500 \mathrm{U} \$ S$ ) but also easy for setting up and operation (generally, a person could operate 4 or more RAINES systems easily). These properties of RAINES ensure that they can be easily used for experimental rainfall studies within semi-arid and arid ecosystems.

Comparison with other rainfall simulators.- Types of rainfall simulators could be roughly categorized into non-pressure and pressure rainfall simulators (Hudson, 1993). Non-pressure rainfall simulators (e.g. trickle irrigation and sprinkling can) were generally simple and inexpensive. Consequently, they were widely employed in rainout shelters, greenhouse and small field experimental units (Bowman, Brunke, 
Reynolds, Wall, 1994; Zavaleta et al., 2003; Huxman et al., 2004a; Lee et al., 2004; Sponseller, 2007; Chen et al., 2008; Fay et al., 2008; Patrick et al., 2009; St Clair, Sudderth, Castanha, Torn, Ackerly, 2009; Robertson et al., 2010). However, they are only used for small plots (usually smaller than $10 \mathrm{~m}^{2}$ ) with flat surface, and were unable to change rainfall intensity, raindrops size and raindrops fall velocity (or raindrops kinetic energy). Therefore, they have not been used for hydrologic and field-based studies with large experimental plots.

In contrast, pressure rainfall simulators could make artificial rainfall closer to natural rainfall properties, such as mixed raindrops distribution and high raindrops kinetic energy (Hudson, 1993). Pressure rainfall simulators could be further classified into fixed- and non-fixed nozzle rainfall simulators (Table 3). Pressure rainfall simulators with fixed nozzle usually employed hanging shower nozzle or oscillating nozzle (or oscillating boom) (Table 3). Shower nozzle rainfall simulators needed to be hung (or mounted) on the head of a plot with metal supports, which not only restricted the rainfall area but also increased the difficulty of operation in field (Table 3). Oscillating nozzle rainfall simulators could cover a larger area, but they usually lack homogeneity in rainfall distribution. Pressure rainfall simulators with non-fixed nozzle included rotating disc, rotating nozzle and rotating boom rainfall simulators, etc. Rotating nozzle (or rotating disc) needed metal supports. The stature of the metal supports could restrict the rainfall area. If more nozzles (e.g. shower nozzle, oscillating nozzle, rotating nozzle, rotating disc, etc) were employed to expand rainfall area, rainfall homogeneity would be declining between transitional zones of the nozzles (Shelton, Von Bernuth, Rajbhandari, 1985; Esteves, Planchon, Lapetite, Silvera, Cadet, 2000; Munster et al., 2006). Consequently, they were also not suitable for a large experimental plot at the field.

Rotating boom rainfall simulators employed several long booms and numerous nozzles (Swanson, 1965; Simanton, Weltz, Larsen, 1991; Sharpley and Kleinman, 2003), which extended plot area and increased the uniformity of rainfall at the field (Table 3), and was suitable for semi-arid and arid ecosystems with sparse vegetation distribution. Unfortunately, rotating boom rainfall simulators are heavy, which make them not only expensive but also difficult to move and operate in remote regions.

Compared with the above mentioned rainfall simulators, the RAINES in the present study was not only versatile enough to simulate various rainfall events with water pressure than non-pressure rainfall simulators (such as trickle irrigation and sprinkling can), but also simple and lightweight. It can be used in large plots in remote fields in semi-arid and arid ecosystems where other pressure rainfall simulators (such as shower nozzle, oscillating nozzle, rotating disc, rotating nozzle and Swanson-type rotating boom rainfall simulators) are impractical (Table 3).

Factors influencing RAINES performance.- The design principles of rainfall simulators and climatic conditions were key factors in determining rainfall intensity, distribution and loss (Gilley et al., 1983; Steiner, Kanemasu, Clark, 1983; Aboghobar, 1993; Weltzin et al., 2003; Munster et al., 2006). Increasing the spraying height of water can increase the residence time of water in air and water spray radius, and therefore decrease the validity of rainfall. For RAINES, the mounted high of the 


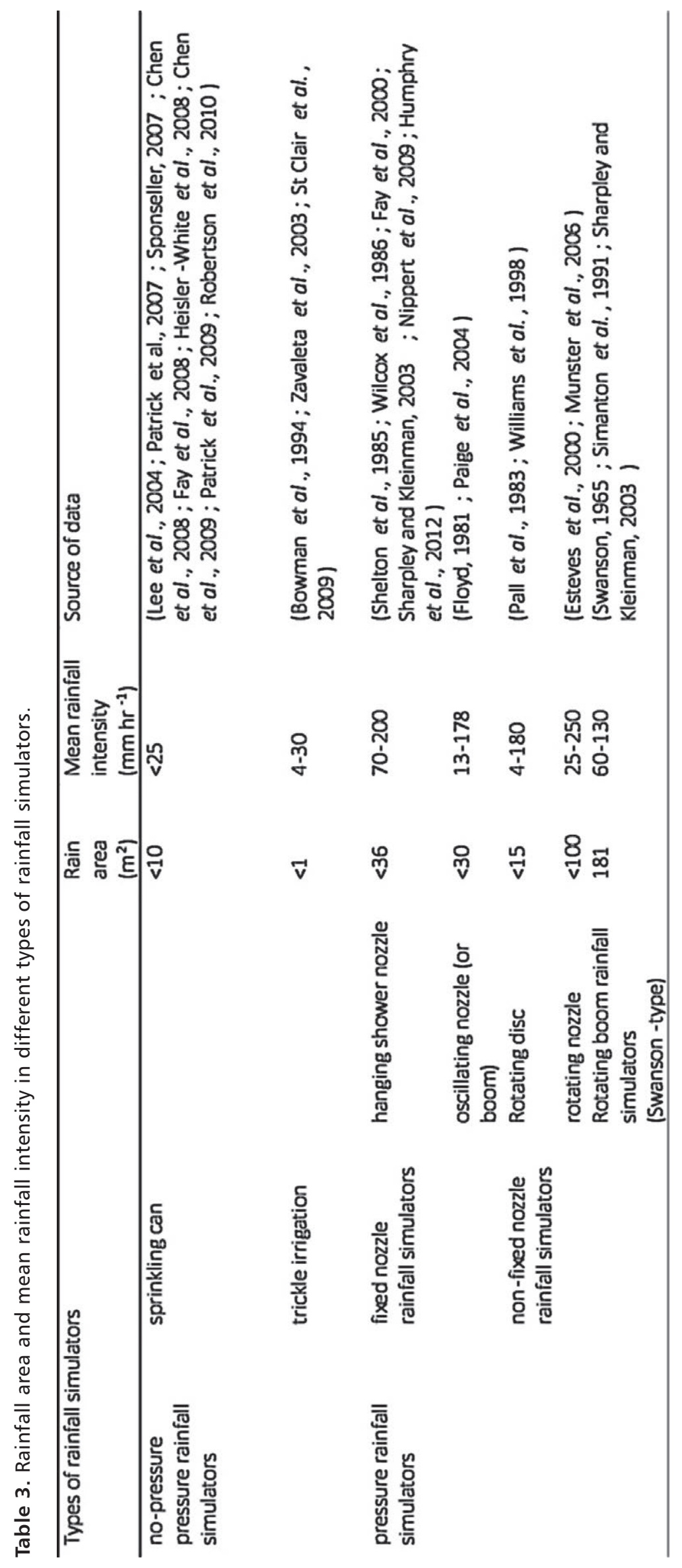




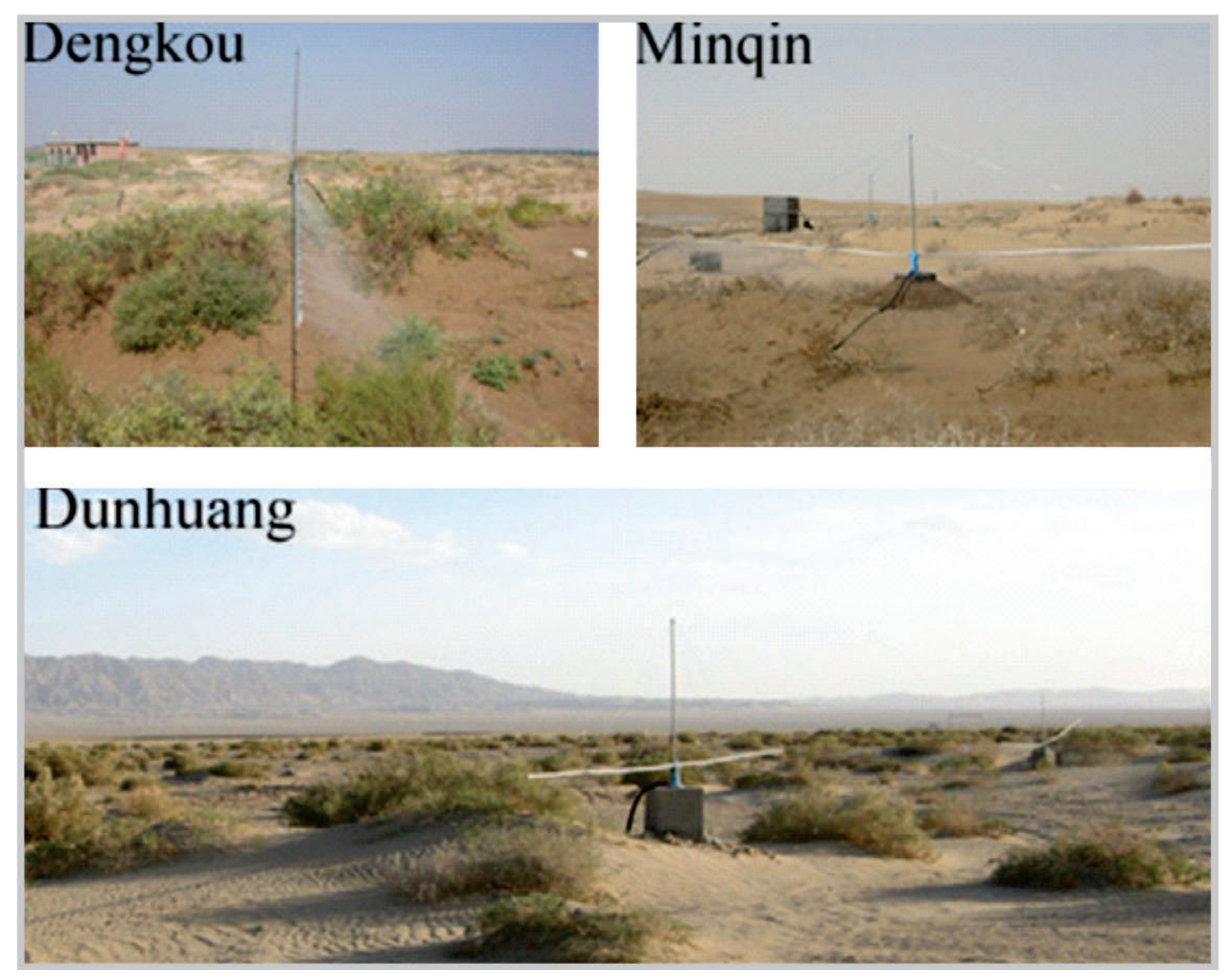

Fig. S1. Supplementary Data - Three study sites (Dengkou-the mean annual precipitation is ca. $145 \mathrm{~mm}$, Minqin-the mean annual precipitation is ca. $115 \mathrm{~mm}$, and Dunhuang-the mean annual precipitation is ca. $40 \mathrm{~mm}$ ) for studying the ecological effects of rainfall pulses in arid ecosystems in natural environment.

rotating booms can be regulated by adjusting the stature of pedestal, which can be useful to reduce water loss in air.

Hydraulic pressure was another factor in influencing rainfall distribution, radius and intensity, which is associated with the nozzle diameter (Gilley et al., 1983; Aboghobar, 1993). Increasing hydraulic pressure can increase rainfall intensity and the uniformity of rainfall distribution in open field experimental plots (Gilley et al., 1983). For RAINES, a hydraulic pressure of $1.4 \mathrm{KPa}$ or higher is necessary to ensure the stable and high rainfall validity. If the pressure is lower than $1.4 \mathrm{KPa}$, the rainfall validity is not only low but also variable.

Wind speed can not only decreases rainfall validity at given location, but also changes the simulated rainfall distribution (Steiner et al., 1983; Aboghobar, 1993). For RAINES, our results showed that the rainfall homogeneity in the plot commonly decreased with increasing wind speed, and the rainfall intensity was generally higher downwind of the experimental plot, but lower upwind of it. We also demonstrated that the maximum wind speed for reliable performance of $R A I N E S$ systems was about $2.5 \mathrm{~m} \mathrm{~s}^{-1}$. 
In addition, temperature and humidity are important in affecting water loss (Steiner et al., 1983; Aboghobar, 1993). Low air humidity can reduce the validity of rainfall simulation because of increasing water vapor pressure variability. High air temperature may increase water molecular kinetic energy, resulting in more water loss during rainfall simulation. Consequently, the validity of rainfall simulation will be lower in hot summer in arid and semi-arid regions because of higher temperatures and lower relative humidities. However, in the present study, we failed to test the performance of RAINES under different temperatures and humidities, but we expect that the above relationships between rainfall validity and these environmental factors are applicable to the RAINES systems.

Implications.- The RAINES we presented in this study is light-weight, inexpensive and versatile enough to be used to simulate various rainfall events with needed properties in remote fields. It is able to provide reliable simulated rainfall in the field for studying possible responses of soil and vegetation processes to rainfall change in arid and semi-arid ecosystems. The application of the RAINES will improve our understanding on the relationship between water availability and ecosystem processes in arid and semi-arid ecosystems, which will provide useful knowledge for the protection, restoration and sustainable management of semi-arid and arid desert ecosystems worldwide.

\section{ACKNOWLEDGEMENTS}

This work was financially supported by the National Key Research and Development Program of China (2017YFC503804-04) and the National Natural Science Foundation of China (41671049).We would like to thank Jun Xun, Fei Sun, Weichun Kong, Jingbao Zhang for their assistances in the field work.

\section{REFERENCES}

Aboghobar, H. M. (1993). Evaporation and drift losses from sprinkler irrigation systems under hot and dry conditions. Fournal of King Saud University 5: 153164.

Bowman, B. T., Brunke, R., Reynolds, D., Wall, G. L. (1994). Rainfall simulatorgrid lysimeter system for solute transport studies using large, intact soil blocks. Fournal of Environmental Quality 23: 815-822. DOI: 10.2134/jeq1994.004724250 02300040029x

Chen, S., Lin, G., Huang, J., Mao, H. (2008). Responses of soil respiration to simulated precipitation pulses in semiarid steppe under different grazing regimes. Fournal of Plant Ecology 1 (4): 237-246. DOI: 10.1093/jpe/rtn020

Chen, S. P., Lin, G. H., Huang, J. H., Jenerette, G. D. (2009). Dependence of carbon sequestration on the differential responses of ecosystem photosynthesis and 
respiration to rain pulses in a semiarid steppe. Global Change Biology 15 (10): 2450-2461. DOI: 10.1111/j.1365-2486.2009.01879.x

Chou, W. W., Silver, W. L., Jackson, R. D., Thompson, A. W., Allen Diaz, B. (2008). The sensitivity of annual grassland carbon cycling to the quantity and timing of rainfall. Global Change Biology 14 (6): 1382-1394. DOI: 10.1111/j.13652486.2008.01572.x

Dunkerley, D. (2008). Rain event properties in nature and in rainfall simulation experiments: a comparative review with recommendations for increasingly systematic study and reporting. Hydrological Processes 22 (22): 4415-4435. DOI: 10.1002/hyp.7045

Esteves, M., Planchon, O., Lapetite, J. M., Silvera, N., Cadet, P. (2000). The 'EMIRE' large rainfall simulator: design and field testing. Earth Surface Processes and Landfoms 25 (7): 681-690. DOI: 10.1002/1096-9837(200007)25:7<681::AIDESP124>3.0.CO;2-8

Fay, P. A., Carlisle, J. D., Knapp, A. K., Blair J. M., Collins, S. L. (2000). Altering rainfall timing and quantity in a mesic grassland ecosystem: design and performance of rainfall manipulation shelters. Ecosystems 3 (3): 308-319. DOI: $10.1007 / \mathrm{s} 100210000028$

Fay, P. A., Kaufman, D. M., Nippert, J. B., Carlisle, J. D., Harper, C. W. (2008). Changes in grassland ecosystem function due to extreme rainfall events: implications for responses to climate change. Global Change Biology 14 (7): 1600-1608. DOI: $10.1111 / j .1365-2486.2008 .01605 . x$

Floyd, C. (1981). A mobile rainfall simulator for small plot field experiments. Fournal of Agricultural Engineering Research 26 (4): 307-314. DOI: 10.1016/00218634(81)90072-x

Gilley, J. R., Mielke, L. N., Wilhelm, W. W. (1983). An experimental center-pivot irrigation system for reduced energy crop production studies. Transaction of the ASAE 26 (5): 1375-1379. DOI: 10.13031/2013.34135

Heisler-White, J. L., Knapp, A. K., Kelly, E. F. (2008). Increasing precipitation event size increases aboveground net primary productivity in a semi-arid grassland. Oecologia 158 (1): 129-140. DOI: 10.1007/s00442-008-1116-9

Hudson, N. W. (1993). Field measurement of soil erosion and runoff. Food and Agriculture Organization of the United Nations (FAO), Rome, Italy.

Humphry, J. B., Daniel, T. C., Edwards, D. R., Sharpley, A. N. (2002). A portable rainfall simulator for plot-scale runoff studies. Applied Engineering in Agriculture 18 (2): 199-204. DOI: 10.13031/2013.7789

Huxman, T. E., Cable, J. M., Ignace, D. D., Eilts, J. A., English, N. B., Weltzin, J., Williams, D. G. (2004a). Response of net ecosystem gas exchange to a simulated precipitation pulse in a semi-arid grassland: the role of native versus non-native grasses and soil texture. Oecologia 141 (2): 295-305. DOI: 10.1007/s00442-0031389-y

Huxman, T. E., Snyder, K. A., Tissue, D., Leffler,A. J., Ogle, K., Pockman, W. T., Sandquist, D. R., Potts, D. L., Schwinning, S. (2004b). Precipitation pulses and carbon fluxes in semiarid and arid ecosystems. Oecologia 141 (2): 254-268. DOI: 10.1007/s00442-004-1682-4 
Lee, X., Wu, H. J., Sigler, J., Oishi, C., Siccama, T. (2004). Rapid and transient response of soil respiration to rain. Global Change Biology 10 (6): 1017-1026. DOI: 10.1111/j.1529-8817.2003.00787.x

Meyer, L. D. (1994). Rainfall simulators for soil erosion research, in: Lal, R., (Eds.), Soil erosion research methods. St. Lucie Press, Delray Beach, Florida, pp. 83103.

Munster, C. L., Taucer, P. I., Wilcox, B. P., Porter, S. C., Richards, C. E. (2006). An approach for simulating rainfall above the tree canopy at the hillslope scale. Transaction of the ASABE 49 (4): 915-924. DOI: 10.13031/2013.21737

Nippert, J. B., Fay, P. A., Carlisle, J. D., Knapp, A. K., Smith, M. D. (2009). Ecophysiological responses of two dominant grasses to altered temperature and precipitation regimes. Acta Oecologica 35 (3): 400-408. DOI: 10.1016/j.actao.2009.01.010

Paige, G. B., Stone, J. J., Smith, J. R., Kennedy, J. R. (2004). The Walnut Gulch Rainfall Simulator: a computer-controlled variable intensity rainfall simulator. Applied Engineering in Agriculture 20 (1): 25-34. DOI: 10.13031/2013.15691

Pall, R., Dickinson, W. T., Beals, D., McGirr, R. (1983). Development and calibration of a rainfall simulator. Canadian Agricultural Engineering 25: 181-187.

Patrick, L., Cable, J., Potts, D., Ignace, D., Barron-Gafford, G., Griffith, A., Alpert, H., Van Gestel, N., Robertson, T., Huxman, T. E., Zak, J., Loik, M. E., Tissue, D. (2007). Effects of an increase in summer precipitation on leaf, soil, and ecosystem fluxes of $\mathrm{CO}_{2}$ and $\mathrm{H}_{2} \mathrm{O}$ in a sotol grassland in Big Bend National Park, Texas. Oecologia 151 (4): 704-718. DOI: 10.1007/s00442-006-0621-y

Patrick, L. D., Ogle, K., Bell, C. W., Zak, J., Tissue, D. (2009). Physiological responses of two contrasting desert plant species to precipitation variability are differentially regulated by soil moisture and nitrogen dynamics. Global Change Biology 15 (5): 1214-1229. DOI: 10.1111/j.1365-2486.2008.01750.x

Renard, K. (1985). Rainfall simulators and USDA erosion research: History, perspective, and future. in: Lane, L.J. (Eds.), Proceedings of Rainfall Simulation Workshop, Tucson, AZ. , Society for Range Manage, Denver, Colorado, pp. 3-6.

Robertson, T. R., Zak, J. C., Tissue, D. T. (2010). Precipitation magnitude and timing differentially affect species richness and plant density in the sotol grassland of the Chihuahuan Desert. Oecologia 162 (1): 185-197. DOI: 10.1007/s00442-0091449-z

Schwinning, S., Sala, O. E., Loik, M. E., Ehleringer, J. R. (2004). Thresholds, memory, and seasonality: understanding pulse dynamics in arid/semi-arid ecosystems. Oecologia 141 (2): 191-193. DOI: 10.1007/s00442-004-1683-3

Sharpley, A. and Kleinman, P. (2003). Effect of rainfall simulator and plot scale on overland flow and phosphorus transport. Fournal of Environment Quality 32 (6): 2172-2179. DOI: $10.2134 /$ jeq2003.2172

Shelton, C. H., Von Bernuth, R. D., Rajbhandari, S. P. (1985). A continuous-application rainfall simulator. Transaction of the ASAE 28 (4): 1115-1119. DOI: $10.13031 / 2013.32397$

Simanton, J., Weltz, M., Larsen, H. (1991). Rangeland experiments to parameterize the water erosion prediction project model: vegetation canopy cover effects. Fournal of Range Management 44 (3): 276-282. DOI: 10.2307/4002957 
Sponseller, R. A. (2007). Precipitation pulses and soil $\mathrm{CO}_{2}$ flux in a Sonoran Desert ecosystem. Global Change Biology 13 (2): 426-436. DOI: 10.1111/j.13652486.2006.01307.x

St Clair, S. B., Sudderth, E. A., Castanha, C., Torn, M. S., Ackerly, D. D. (2009). Plant responsiveness to variation in precipitation and nitrogen is consistent across the compositional diversity of a California annual grassland. Fournal of Vegetation Science 20 (5): 860-870. DOI: 10.1111/j.1654-1103.2009.01089.x

Steiner, J., Kanemasu, E., Clark, R. (1983). Spray losses and partitioning of water under a center pivot sprinkler system. Transaction of the ASAE 26 (4): 1128-1134. DOI: $10.13031 / 2013.34090$

Swanson, N. P. (1965). Rotating-boom rainfall simulator. Transaction of the ASAE 8: 71-72. DOI: $10.13031 / 2013.40430$

Weltzin, J. F., Loik, M. E., Schwinning, S., Williams, D. G., Fay, P. A., Haddad, B. M., Harte, J., Huxman, T. E., Knapp, A. K., Lin, G., Pockman, W. T., Shaw, R. M., Small, E. E., Smith, M. D., Tissue, D. T., Zak, J. C. (2003). Assessing the response of terrestrial ecosystems to potential changes in precipitation. Bioscience 53 (10): 941-952. DOI: 10.1641/0006-3568(2003)053[0941:ATROTE]2.0.CO;2

Wilcox, B. P., Wood, M. K., Tromble, J. T., Ward, T. J. (1986). A hand-portable single nozzle rainfall simulator designed for use on steep slopes. Fournal of Range Management 39 (4): 375-377. DOI: 10.2307/3899784

Williams, J. D., Wilkins, D. E., McCool, D., Baarstad, L. L., Klepper, B. K., Papendick, R. I. (1998). A new rainfall simulator for use in low-energy rainfall areas. Applied Engineering in Agriculture 14 (3): 243-247. DOI: 10.13031/2013.19385

Zavaleta, E. S., Shaw, M. R., Chiariello, N. R., Thomas, B. D., Cleland, E. E., Field, C. B., Mooney, H. A. (2003). Grassland responses to three years of elevated temperature, $\mathrm{CO}_{2}$, precipitation, and $\mathrm{N}$ deposition. Ecological Monographs 73 (4): 585-604. DOI: 10.1890/02-4053 